\section{OP0284-PARE THE INFLUENCE OF FUNCTIONAL TRAINING AND PSYCHO-SOCIAL SUPPORT}

\section{Nenad Nedić, Mirjana Lapčević. Belgrade, Belgrade, Serbia}

Background: Treatment of chronic noncontagious diseases in which we include RMD implies usage of medicines and non medicine (changing bad lifestyle habits like losing nutrition, physical activity, smoking...). ${ }^{1}$ Unwanted cardiovascular and cerebrovascular states are the most common cause of shortening of live of people with RMD. ${ }^{2}$ None of the chemical drugs can replace physical activity. Physical activity dosage is individual, and depends on aerobic capability and heart rate increase, taking in account age, type of noncontagious diseases, level of tissue and organs damage as well as the type of work the person is engaged in.

Patients with RMD have common symptoms, such as stiffness, fatigue, poor mobility, joint pain and muscle pain, anxiety and depression, and lack of fitness. In addition to physical medicine and rehabilitation and balneoklimatology, various forms of physical activity are recommended, such as walking, swimming, functional training. Today, moderate physical activity is known to help reduce fatigue, strengthen muscles and bones, improve flexibility and endurance of the joints, and improve general health. It is necessary to find the best combination of rest, activities and exercise programs to prevent deformities of the joints, the development of disability, improve the quality of life, and the mental health of patients with $\mathrm{RMD}^{3}$

Objectives: 1. By practicing Cigong, an increase in the volume of movement in the joint, the strengthening of joint muscles and the improvement of general condition, pain relief, fatigue reduction is achieved and also, it helps patients look and feel better.

2. The goal of Yoga is to neutralize and remove all obstacles that stand in the way and disturb the function of the body and the mind and achieves inner peace.

3. Changing the psychological state during exercise also led to a positive way of thinking.

4. Psycho-physical support for the people with RMD

Methods: From 2011, we organize two times a week functional training of Cigong. ${ }^{4}$

Since January 2016, twice a week persons with RMD have been practicing Yoga. ${ }^{5}$

From 2015, one per week four psychologists volunteer hold workshops for psycho-social support for persons with RMD.,

Participants of the training and psycho-social sessions took a survey.

Results: 1 . Joint pain reduction $-50 \%$ of total number of participants

2. Joint mobility increase $-95 \%$ of total number of participants

3. General fitness improvement $-73 \%$ of total number of participants

4. Less pronounced negative emotions $-59 \%$ of total number of participants

Conclusion: Practicing cigong, yoga and psycho-social support workshops help patients look better and feel better. Changing the psychological state during exercise also led to a positive way of thinking. All of this increased the effectiveness of drug treatment and improved the quality of life of patients with RMD.

\section{REFERENCES:}

[1] Dragojević R. Vodič za zdrav život: preporuke medicine i pouke mudrosti, Beograd 2017.

[2] Lapcević M., Vuković M. Dimitrijevic I. Et all Uticaj medikamentnog I nemedikamentnog lečenja na smanjenje faktora rizika za kardiovaskularne I cerebrovaskularne događaje u interventnoj studiji. Srp Arh Celok Lek 2007.

[3] Lapčević M, Prvanov D, Đorđević S. Procena kvaliteta života obolelih od hroničnih reumatskih oboljenja. Opšta medicina 2010.

[4] Ilinka Acimovic, "The Influence of Health Qigong on the Subjectively Expressed Psychophysical State of Patients with Rheumatoid Arthritis, Rheum, Osteoporosis, Osteopenia" CHINESE MEDICINE AND CULTURE

[5] Swami Kriyananda, "Demystifying Patanjali: The Yoga Sutras - The Wisdom of Paramhansa Yogananda". Crystal Clarity Publishers, Nevada City, CA, 2013.

[6] Lapčević $M$, et al. Socioeconomic and therapy factor influence on selfreported fatigue, anxiety and depression in rheumatoid arthritis patients. Rev Bras Reumatol. 2017.

[7] Milić V. Analiza ličnosti I uticaj optimizma na pozitivan ishod lečenja; 2018.

Disclosure of Interests: None declared

DOI: 10.1136/annrheumdis-2019-eular.4256

\section{OP0285-PARE SARCOPENIA IN PATIENTS WITH RHEUMATIC DISEASES}

Jürgen Clausen ${ }^{1}$, Roswitha Dietzel ${ }^{2}$, Gabriele Armbrecht ${ }^{2} .{ }^{1}$ Deutsche RheumaLiga Bundesverband e.V., 53111 Bonn, Germany; ${ }^{2}$ Charité - Universitätsmedizin Berlin - Campus Benjamin Franklin, Zentrum f. Muskel- und Knochenforschung, 12200 Berlin, Germany

Background: Sarcopenia is a rather new term, coined in 1989: only in 2016 the International Classification of Disease (ICD) code was established for this disease. Sarcopenia describes a state of reduced muscle mass together with reduced muscle strength and reduced muscle performance that comes with aging. The topic is of great relevance for people with rheumatic diseases, because chronic inflammations and lack of exercise, among others, have been identified as risk factors for the development of sarcopenia. To shed additional light on this emerging field, the German Rheumatism League has funded a participatory research project for the investigation of sarcopenia.

Objectives: The aim of the study was to investigate the prevalence of sarcopenia in patients with rheumatoid arthritis. In addition, the study aimed at identifying risk factors and biomarkers for the development/diagnosis of sarcopenia. The results of the study are intended to enhance the diagnostic tools for recognising sarcopenia in patients with rheumatoid arthritis and to allow the formulation of specific exercise recommendations for the prevention of sarcopenia. Based on the results of the study and additional information from the literature, an information leaflet or brochure for patients will be prepared.

Methods: Participants were screened by medical questionnaires. Blood chemistry was analysed. Body composition was assessed by dual-energy X-ray absorptiometry (DXA). Muscle area and muscle density were measured using peripheral quantitative computed tomography ( $\mathrm{pQCT}$ ). Various neuromuscular tests were performed to assess muscle performance, muscle strength and sense of balance. Additional information on treatment options, prevention and detection were retrieved in a comprehensive literature search. Two "Patient Research Partners" are involved in the study.

Results: The study has not yet been completed. So far, 269 patients (age 18 and older; 216 female, 53 male) were recruited until December 2018. Mean age of participants was 59 years, mean DAS-28 was 2.4 (remission). The control group consisted of an existing cohort of 280 individuals without chronic inflammatory diseases or muscle paralysis (153 females, 127 males, mean age 63 years). Preliminary data show that prevalence of sarcopenia is higher in patients with rheumatoid arthritis compared to the control group. Literature revealed that physical exercise has a positive effect on sarcopenia. In addition, amino acid supplementation, nutritional interventions and hormones might be effective in the treatment of sarcopenia.

Conclusion: The higher prevalence of sarcopenia in patients with rheumatoid arthritis illustrates the urgent need to provide education on sarcopenia for patients with rheumatic diseases.

Disclosure of Interests: Jürgen Clausen: None declared, Roswitha Dietzel Grant/research support from: Yes, but not for the current project on sarcopenia., Speakers bureau: Yes, but not for the current project on sarcopenia., Gabriele Armbrecht Grant/research support from: Yes, but not for the current project on sarcopenia., Consultant for: Yes, but not for the current project on sarcopenia., Speakers bureau: Yes, but not for the current project on sarcopenia.

DOI: 10.1136/ANNRHEUMDIS-2019-EULAR.2072:

\section{OP0286-PARE DEVELOPING A VIRTUAL ASSISTANT TO PROMOTE EDUCATION ON OSTEOARTHRITIS}

Catarina Cavique ${ }^{1}$, Ana Paula Cláudio ${ }^{1}$, Maria Beatriz Carmo ${ }^{1}$, Mara Pereira Guerreiro ${ }^{2}$, Afonso Cavaco ${ }^{3}$, Elsa Mateus ${ }^{4} .{ }^{1} \mathrm{BiolSI}$, Faculdade de Ciências, Universidade de Lisboa, Lisboa, Portugal; ${ }^{2}$ UlandDE, Escola Superior de Enfermagem de Lisboa and CiiEM, Instituto Universitário Egas Moniz, Lisboa, Portugal; ${ }^{3}$ iMed, Faculdade de Farmácia, Universidade de Lisboa, Lisboa, Portugal; ${ }^{4}$ Liga Portuguesa Contra as Doenças Reumáticas, Lisboa, Portugal

Background: Osteoarthritis $(O A)$ is one of the most prevalent chronic rheumatic diseases (24\% in Portugal, according to the Portuguese Society of Rheumatology) accounting for significant years of disability. Optimal management of OA requires active patient participation. A recent systematic review concluded that more effective information strategies are needed to respond to the needs of OA patients. $^{1}$

Interactive computational simulation with Virtual Humans $(\mathrm{VH})$ has been used with the purpose of educating or promoting lifestyle change in healthy people or in 